\title{
Diversity of fruit fly (Diptera: Tephritidae) species in French Guiana: their main host plants and associated parasitoids during the period 1994-2003 and prospects for management
}

Jean-François VAYSSIÈres ${ }^{1 *}$, Jean-Pierre $\mathrm{CAYOL}^{2}$, Philippe CAPLONG ${ }^{3}$, Julien SÉGURET ${ }^{4}$, David MIdGARDEN ${ }^{5}$, Aliès VAN SAUERS-MULLeR ${ }^{6}$, Roberto ZUCCHI $^{7}$, Keiko URAMOTO ${ }^{8}$, Aldo MALAVASI ${ }^{9}$

${ }^{1}$ CIRAD, Persyst, UPR HortSys, 34398 Montpellier, France; IITA, Biol. Cont. Unit Afr., 08 BP 0932, Cotonou, Benin

J.Vayssieres@cgiar.org

2 IAEA, Programme Action Cancer Ther. (PACT), PO Box 100, A-1400 Vienna, Austria

${ }^{3}$ Chamb. Agric., Rue Alcide Desmazures, La Flotille BP 111, 98845 Noumea Cx, N. Calédonie

${ }^{4}$ BIOTOP, 1306, route de Biot, 06560 Valbonne, France

${ }^{5}$ APHIS-USDA, Medfly Techn. Dir., Guatem. City, Guatemala

${ }^{6}$ Carambola Fruit Fly Program, Agric. Exp. Stn., Minist. Agric., Paramaribo, Suriname

${ }^{7}$ Dep. Entomol. Acarol., Esc. Sup. Agric."Luiz de Queiroz", USP, Piracicaba, São Paulo, Brazil

8 Inst. Biociênc., Univ. São Paulo, Av. Padua Dias, 11, Cep 13418-900, São Paulo, Brazil

${ }^{9}$ Moscamed Brazil , Quadra D13, Lote 15, 48.900-000, Juazeiro, Bahia, Brazil

* Correspondence and reprints

Received 1 May 2012

Accepted 30 July 2012

Fruits, 2013, vol. 68, p. 219-243 (c) 2013 Cirad/EDP Sciences All rights reserved DOI: $10.1051 /$ fruits/2013070 Www.fruits-journal.org

RESUMEN ESPAÑol, p. 243
Diversity of fruit fly (Diptera: Tephritidae) species in French Guiana: their main host plants with associated parasitoids during the period 1994-2003 and prospects for management.

Abstract - Introduction. This study was carried out in French Guiana, over ten years (1994-2003) by three institutions (SPV, FDGPC and CIRAD); it updates the current state of knowledge of Tephritidae (both Dacini and Toxotrypanini tribes) species present in this country. Materials and methods. The work was mainly conducted in inhabited areas (from the Brazilian border to the Surinamese border) where cultivated fruit crops are located. Specimens were obtained by adult trapping and fruit sampling in nearby orchards and at the edge of the rainforest. Trapping was done consistently for 10 years, while fruit sampling was a discontinuous activity. We present only the results for fruit sampling from three consecutive years (2001-2003) in which a total of $880 \mathrm{~kg}$ from 45 fruit species in 22 plant families were collected. Results. Twenty-nine plant species from fourteen plant families were found to be hosts of twenty-one Anastrepha species and one Bactrocera species, Bactrocera carambolae Drew and Hancock. During this period, no specimen of Ceratitis capitata (Wiedemann) was collected in traps or fruit samples. We registered the main fruit trees which were hosts for B. carambolae and Anastrepha spp. Five hymenopterous parasitoid species were identified. Among them, Diachasmimorpha longicaudata (Ashmead) (Hymenoptera, Braconidae) is an exotic species and was introduced into French Guiana in collaboration with Brazilian authorities (EMBRAPA) in 2000 and 2001 within the framework of a classical biological control program. Conclusion. Our data provide baseline information about the tephritid species of economic importance present in French Guiana and assist in developing potential future control programs of both the B. carambolae and Anastrepha species in the Amazon Basin. These preliminary results are discussed in the light of their implication for rainforest conservation efforts and also evolutionary relationships between fruit flies and their hosts.

French Guiana / fruit trees / host plants / fruit-damaging insects / data collection / Tephritidae / Braconidae / Bactrocera carambolae / Anastrepha

Diversité des espèces de mouches des fruits (Diptera : Tephritidae) présentes en Guyane française: leurs principales plantes-hôtes et leurs parasitoïdes durant la période 1994-2003, et perspectives de lutte.

Résumé - Introduction. Cette étude s'est déroulée en Guyane française durant dix ans (1994-2003) grâce à trois institutions (SPV, FDGPC, CIRAD) ; elle apporte sa contribution à un inventaire des espèces de Tephritidae (Dacini and Toxotrypanini) dans ce pays. Matériel et méthodes. Cet inventaire concerne les zones habitées de la Guyane française de la frontière brésilienne à la frontière surinamienne et concerne les localités hébergeant des cultures fruitières. Les Tephritidae ont été obtenues par piégeage des adultes et échantillonnages de fruits autour des vergers et en bordure de la forêt pluviale. Le piégeage a duré globalement une dizaine d'année tandis que les échantillonnages de fruits ont été effectués de façon discontinue. Nous présentons les résultats de trois années consécutives (2001 à 2003) durant lesquelles un total de $880 \mathrm{~kg}$ de fruits, avec 45 essences fruitières représentant 22 familles, a été récolté. Résultats. Vingt neuf espèces fruitières appartenant à quatorze familles sont les hôtes de vingt et une espèces d'Anastrepha et d'une espèce de Bactrocera, Bactrocera carambolae Drew and Hancock. Durant cette période, aucun specimen de Ceratitis capitata (Wiedemann) n'a été capturé dans les pièges ou n'a émergé des récoltes de fruits. Nous présentons les principales espèces fruitières hôtes de B. carambolae et Anastrepha spp. Nous avons identifié cinq espèces d'hyménoptères parasitoïdes. Parmi elles, Diachasmimorpha longicaudata (Ashmead) (Hymenoptera, Braconidae) est une espèce exotique qui a été introduite en Guyane française en 2000 et 2001 en collaboration avec les autorités brésiliennes (EMBRAPA), dans le cadre d'un programme de lutte biologique. Conclusion. Ces observations préliminaires peuvent apporter des informations basiques dans l'éventualité de la reprise des programmes de lutte contre $B$. carambolae et contre les principales espèces d'Anastrepha dans le bassin amazonien. Ces résultats sont discutés dans l'optique de leur valorisation pour la protection des forêts primaires, mais également de l'évolution des relations insectes-plantes.

Guyane française / arbre fruitier / plante hôte / insecte déprédateur des fruits / collecte de données / Tephritidae / Braconidae / Bactrocera carambolae / Anastrepha 


\section{Introduction}

In South America, flies within the Anastrepha, Ceratitis [1-6] and, more recently, Bactrocera [7-12] genera cause substantial damages to commercial (and non-commercial) fruits. Anastrepha is the only genus native to the New World and is the most diverse and economically damaging genus of Tephritidae in the Neotropical region; it is commonly limited to tropical and subtropical areas [1, 13, 14], although there are some species that inhabit temperate areas as well [5]. The taxonomy and the zoogeography of the genus Anastrepha have been studied by many authors [2, 3, 13, 15] and new species are regularly described [16-19]. At the same time, Anastrepha species have revealed remarkable biological, ecological and behavioral traits [1, 20, 21].

Our study focused on the diversity of fruit fly species (both Dacini and Toxotrypanini tribes) captured or reared in French Guiana during ten consecutive years from 1994 to 2003. Many articles have been published on tephritids from the New World, in South America as well as in other parts of the Neotropical region; however, a brief review of the fruit fly research in French Guiana showed that very little has been published regarding the fruit flies present, either as a list of species present or describing the damages they cause. We hope that this publication using data collected over a decade will add to the bulk of information on tephritid species in the region and update the information known from French Guiana. The goal of much of the trapping and sampling that resulted in the information reported here was part of an eradication program. This program targeted Bactrocera caram bolae Drew \& Hancock, the Carambola Fruit Fly (CFF), in the framework of a regional control program in collaboration with national plant health authorities in Brazil, Suriname and Guyana, and the Instituto Interamericano de Cooperación para la Agricultura (IICA).

French Guiana benefits from a humid tropical climate. The rainy season lasts from January to July, with a peak in May, and a dryer month in March, while the dry season runs from August to December, though rains can occur even during this period. Daytime temperatures are higher in the forest than on the coast, while night temperatures are a little cooler. Humidity remains high throughout the territory and daytime temperatures are constant (around $28^{\circ} \mathrm{C}$ ). The rainforests of French Guiana are largely unexploited and scarcely populated. Overall, more than 90\% of French Guiana is forested; about $95 \%$ consists of primary forest $(7,701,000 \mathrm{ha})$. French Guiana is home to at least 5,625 species of vascular plants of which $3 \%$ are endemic.

Trapping surveys to collect fruit flies in French Guiana began during the second half of the 1990s. During the initial stage of this survey, traps were the most commonly used tool. They provided information about the location, diversity and population dynamics of fly species but did not provide information about hosts. Later phases included samples of cultivated and wild fruits to associate tephritid species with their hosts. In 2000, a French team [Service de Protection des Végétaux (SPV), Fédération Départementale des Groupements de Protection des Cultures (FDGPC) and Centre de Coopération Internationale en Recherche Agronomique pour le Développement (CIRAD)] focused on four species considered to have the greatest economic impact: Bactrocera carambolae, Anastrepha striata Schiner, A. obliqua (Macquart) and $A$. serpentina (Wiedemann). The latter three tephritid species are native and respectively associated with guavas (Psidium guajava L.), purple mombin (Spondias purpurea L.) and star apple (Chrysophyllum cainito L.) as their main hosts. The first species, B. carambolae, is a relatively new invasive species, originating from Southeast Asia, and first collected in Suriname in 1975 [22].

Bactrocera carambolae was not collected again until 1981 in Suriname. Then, these adults were sent for taxonomic identification and initially named as Dacus dorsalis, to be later called Bactrocera dorsalis Hendel, the oriental fruit fly. Although the oriental fruit fly is considered to be one of the most serious tephritid pests worldwide, no action was taken at this time. In 1986, many countries realized that the presence of the oriental fruit 
fly in Suriname presented a threat to fruit production and marketing throughout the tropical Americas and the Caribbean. However, in 1994, this fly species was considered to be a separate species from the oriental fruit fly and was described as Bactrocera carambolae Drew and Hancock, 1994, and named the 'carambola fruit fly'. Bactrocera carambolae was detected in French Guiana in 1989, in Guyana (along the eastern border) in 1993, and in Brazil in March 1996 (along the Oyapock River). Failure to quickly detect and identify this invasive species led to its spread in northern South America. Increased control of the carambola fruit fly may impede the further spread of this fly pest.

Apart from the four target species, there were a number of tephritids collected during the 10-year survey. These specimens were not immediately identified, but kept in alcohol for later analysis. One result of this preliminary inventory in French Guiana is that only a small percentage of the 213 tephritids described as Anastrepha species endemic to the New World and restricted to both tropical and subtropical environments were found [21].

Our study can serve to meet four objectives: (i) to update a preliminary list of fruit fly species (Dacini and Toxotrypanini) known to be present in French Guiana from 1994 to 2003; (ii) to document the fly-host associations and infestation rates of some of these species on both introduced and native fruits; (iii) to provide some tritrophic relationships among hosts-tephritids-parasitoids, and (iv) to gather baseline information helpful in launching new programs focused on the study and control of carambola fruit fly and Anastrepha species in the Amazon Basin.

This synthesis of ten years of work provides baseline data for future studies on fruit flies in French Guiana.

A future article will demonstrate the effectiveness of the Male Annihilation Technique (MAT) implemented with success in French Guiana [11], and in Suriname [23].

\section{Materials and methods}

\subsection{Location and area of orchards in French Guiana}

Investigations were carried out in 2000 2002 to locate orchards of different fruit species and to assess their respective production areas. We used satellite views in order to identify orchards that might otherwise be hidden in the rainforest. Visits to place traps and collect samples were made by car where possible or by boat along rivers, as there are few roads outside the inhabited coastal areas of the country. The data presented show the location of fruit production from the year 2002 .

\subsection{Preliminary inventory of fruit fly species with trapping and fruit sampling}

Trapping was carried out for ten years (1994-2003) using food-based attractants in McPhail traps and methyl eugenol baits in Jackson traps. While Jackson traps were used to capture males of carambola fruit fly, mostly females of all tephritid species were captured with McPhail traps baited with Torula pellets in and around orchards. Foodbased baits were available to attract tephritid species including fruit juices (e.g., guava, grape, orange) or commercially available protein hydrolysates (e.g., Torula yeast and Buminal). Protein hydrolysates are generally considered the most effective for most tephritid species. Occasionally, food-baited traps were also placed at the edge of the rainforest. Furthermore, cultivated and wild fruits were sampled in multiple sites in all regions of French Guiana. They were randomly collected from plants bearing nearly ripe or fully ripe fruits (table I). Fruits were collected from the trees, or selected from recently fallen fruits on the ground under the trees. Some wild species are very tall and present significant difficulty in collecting fruit directly from the tree. 


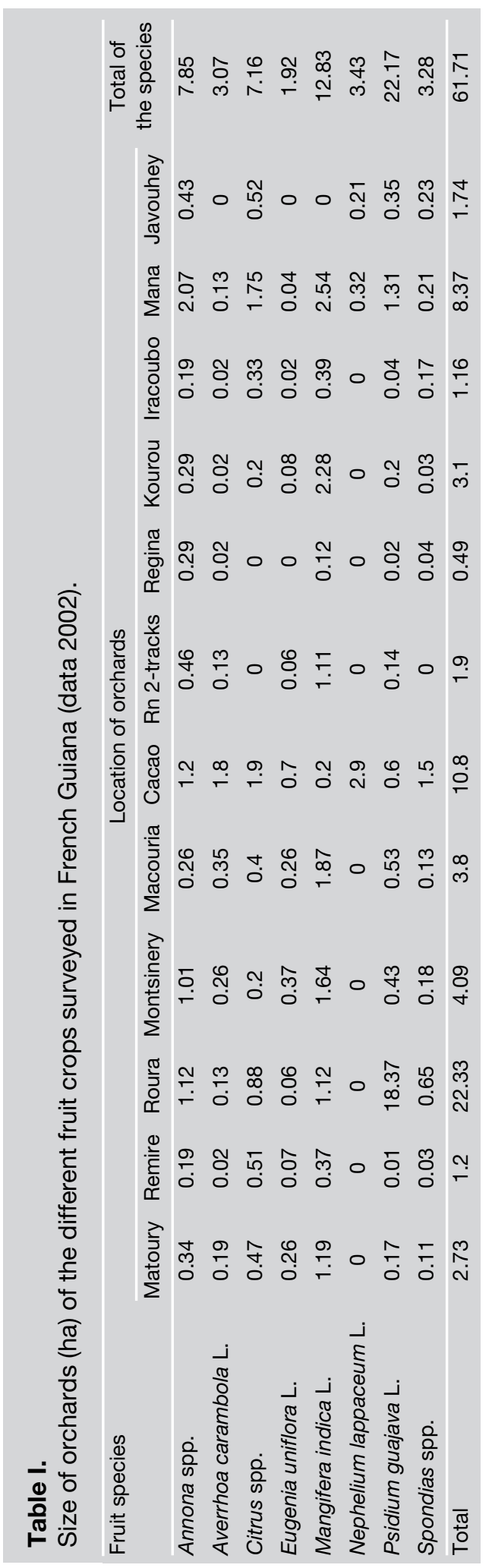


Fruits were packed in screened coolers and taken to the Entomology Laboratory of CIRAD in Kourou (French Guiana). Fruits were counted, weighed and placed in plastic trays with a layer of sterilized sand at the bottom covered by a nylon mesh. The collected larvae were reared in laboratory cages. Once a week, the sand covering the bottom of the containers was washed and then sieved to collect the pupae which had formed during the week. The pupae, collected with flexible tweezers, were then given a reference number and held in small hatchery boxes lined with moist blotting paper (under $25^{\circ} \mathrm{C}$ and $75 \% \mathrm{HR}$ ). The emergence status was checked every three days to collect the adults, which were then identified using a binocular magnifier. Whenever we found difficulties determining a case, the insect was mounted on polypore to confirm identification based upon morphological criteria.

\subsection{Fruit infestation rates and fruit fly parasitoid species}

We calculated (i) the fruit infestation rate (FIR) as the mean number of adults obtained per $\mathrm{kg}$ of sampled fruits over three years (2001-2003); (ii) the percentage of parasitism (PP) as the number of parasitoids (P) emerged per $(\mathrm{P}+$ pupae $)(\times 100)$ over 4 years (1999, 2001-2003), and (iii) the percentages of the main fly species involved in infestations of the same fruit species in 1996 and in 2003 (i.e., two snapshots at an interval of 7 years). A sub-sample of newly emerged tephritid adults was freshly mounted for a few specimens and the rest of the specimens were placed in vials containing $70 \%$ ethanol. Any parasitoids that emerged from the pupae were also kept in vials containing $70 \%$ ethanol.

\subsection{Determinations of fruit fly and parasitoid species}

We identified the most common species ourselves, i.e., Bactrocera carambolae, Anastrepha striata, $A$. obliqua and $A$. serpentina. Determinations of all other Anastrepha species were made by Ian White [British Natural
History Museum (BNHM, London, UK], Gérard Delvare (CIRAD, Montpellier, France), Keiko Uramoto (Univ. de Sao Paulo, São Paulo, Brazil) and Roberto A. Zucchi Escola Superior de Agricultura "Luiz de Queiroz" (ESALQ), Piracicaba, Brazil]. Determinations of parasitoid species were made by Romulo Carvalho [Empresa Brasileira de Pesquisa Agropecuária (EMBRAPA), Cruz das Almas, Brazil], Gérard Delvare (CIRAD, Montpellier, France) and also Jorge A. Guimarães (ESALQ, Piracicaba, Brazil). Voucher specimens were deposited in the collections of the BNHM (London, UK) and CIRAD (Montpellier, France). Only identified specimens which were checked were considered in our studies.

\section{Results and discussion}

\subsection{Location and area of orchards}

During the period 2001-2003, fruit production was not yet well developed in French Guiana. Some small plantations were scattered in twelve different areas within three main zones (Roura, Cacao and ManaJavouhey). Many fruit trees were also found in backyards in urban/suburban areas. It was not easy to find reliable information about the areas of all the orchards though we measured some of them.

About twenty cultivated fruit species were identified in French Guiana in 2002, covering more than 60 ha (total) in the northern part of this country (figure 1, table I). An early draft of fruit production areas was provided by the Direction de l'Agriculture et de la Forêt (DAF) of Cayenne in 2001, and we updated it in 2002. In 2002, the most commonly produced fruit crops were Psidium guajava L., with more than 22 ha, followed by Mangifera indica L. ( 13 ha), not always grafted, Annona spp. ( 8 ha) and Citrus spp. ( 7 ha), all grafted. The surfaces occupied by the other fruit species (Averrboa carambola L., Eugenia uniflora L., Nephelium lappaceum L., Syzygium spp. and Spondias spp.) were not significant.

The three main fruit production zones were Roura ( 22 ha) and Mana-Javouhey 
Figure 1.

General map of French Guiana.

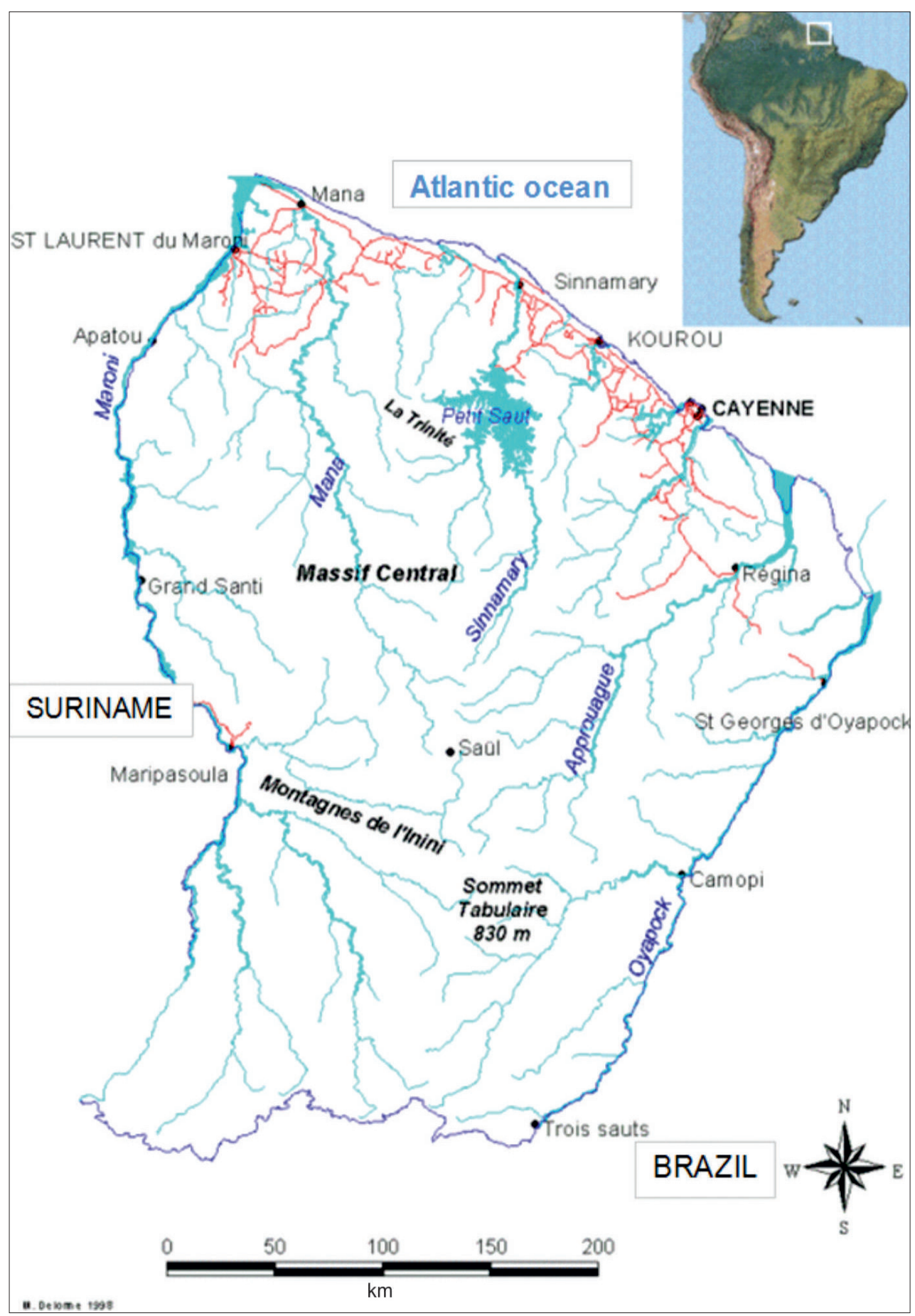

( $\sim 10$ ha), which are located in coastal areas, and Cacao $(\sim 11 \mathrm{ha})$, which is inland. Fruit crops were planted and managed in the areas of Mana-Javouhey and Cacao by an Asian ethnic group which originates from

the Laos Asiatic people ("Hmong" or "Mong"). The people in this community are considered to have both good technical agricultural skills and perseverance. The growers did not use chemical pesticides. 
During the years 2001 and 2002, we also recorded the phenology of flowering and fruiting periods of each fruit species (annex I). Most of the fruit species presented several seasons of fruit production per year, which provides a very favorable environment for fruit fly reproduction throughout the year.

\subsection{Inventory of fruit fly species}

The results of the inventory of fruit fly species which were captured both by trapping and also after emergence from fruit collections are presented. For instance, in 2003 , we had a relatively large area with traps from Macouria to the Brazilian border, with 319 Jackson traps and 79 McPhail traps. At this time, it was the "action zone" where the carambola fruit fly control with both the Male Annihilation Technique and biocontrol activities was developed along the Brazilian border. The McPhail traps provided the most interesting results of fly diversity attracted with Torula pellets, while Jackson traps captured only males of B. carambolae. These last traps were used for carambola fruit fly detection and the monitoring of its population fluctuations.

A total of $880 \mathrm{~kg}$ of fruits representing 45 fruit species, in 22 plant families, were sampled during this 3-year study (20012003). An average of $76 \%$ of B. carambolae, 16\% of Anastrepha striata, $4 \%$ of $A$. obliqua, $3 \%$ of $A$. serpentina and $1 \%$ of other Anastrepha species were obtained from these samples of 29 plant species during these 3 years.

In general, from both trapping activities and fruit collections, one Dacini and twenty-one Toxotrypanini species (annex II) were obtained, namely B. carambolae, Anastrepha striata, A. serpentina, A. obliqua, A. leptozona Hendel, $A$. fraterculus (Wiedemann), $A$. bendeliana Lima, $A$. nigrivittata Norrbom \& Korytkowiski, $A$. ethalea (Walker), A. coronilli Carrejo \& Gonzales, A. shannoni Stone, A. distincta Greene, A. maniboti Lima, A. furcata Lima, $A$. sororcula Zucchi, A. antunesi Lima, A. sagittata (Stone), $A$. anomala Stone, $A$. mucronata Stone, A. atrigona Hendel, $A$. pickeli Lima and $A$. sp. aff. pseudoparallela (Loew). Furthermore, three probably new Anastrepha species were also captured in McPhail traps, but these specimens were in bad condition. The references, localities, dates and hosts or the traps in which the specimens were encountered were recorded (annex II). Of course, we have not included a list of locations and dates for all captures. We tried to present the wider list of fruit fly species captured with their main hosts. It is worth mentioning that, during this period (1994-2003), no specimen of Ceratitis capitata (Wiedemann) was found in French Guiana.

The fraterculus species group was the largest group recorded in our sample. It was represented by five species: Anastrepha antunesi, $A$. coronilli, $A$. distincta, $A$. obliqua and $A$. fraterculus. According to both morphological and mitochondrial DNA phylogenies, it is the largest Anastrepha species group [24]. This group is also considered to be the most derived one [13]. Anastrepha fraterculus is a complex of cryptic species which shows physiological and morphological differences [25, 26]. In fact, the actual number of putative species within the $A$. fraterculus complex and their associated biogeography is still uncertain. Consequently, differences among cryptic species could have significant consequences for pest quarantine, management and eradication issues. It is the same problem with the large cluster of species (over 50) of the B. dorsalis complex in Asia [27].

The spatulata species group was the second largest subdivision of Anastrepha found, represented by two species; $A$. maniboti and $A$. pickeli. The serpentina and leptozona groups were represented by one species each, $A$. serpentina and $A$. leptozona, respectively. We noted that some specimens of $A$. serpentina presented slight differences in their aculeus. We also received from Ian White some specimens similar to A. serpentina, which were identified as Anastrepha sp. aff. serpentina in 1998. According to Norrbom, care is warranted when referring to some specimens of $A$. serpentine [28]. 


\subsection{Fruit fly species and their main hosts}

Host information is essential for studies on the biology and ecology of tephritid species. The hosts of many tephritid species are still unknown, and Uramoto et al. noted that over 50\% of the 213 described Anastrepha species have no host data [21].

First of all, given French Guiana's vast territory and the diversity of both Anastrepha and plant species, these data should be considered preliminary and incomplete. Second, pupae from different species were kept under the same environmental conditions. These conditions could favor the development of one species more than others because pupae mortality could be different among species. So, the results of fly species and also parasitoid species should be analyzed with caution in this regard.

Bactrocera carambolae infested 23 fruit species belonging to 11 families (annex III). Its main host was Averrboa carambola (Oxalidaceae), with an average of 184 fly adults per $\mathrm{kg}$ fruit. The amount of flies emerged per $\mathrm{kg}$ fruit for each host was: 76 flies from Syzygium malaccense Merr. \& Perry (Myrtaceae), 71 from Syzygium samarangense Merr. \& Perry (Myrtaceae), 43 from Spondias dulcis Foster (Anacardiaceae) 31 from S. mombin (Anacardiaceae), 23 from Malpighia punicifolia L. (Malpighiaceae), 11 from Eugenia uniflora L. (Myrtaceae), 10 from Psidium guajava and 8 from Terminalia catappa L. (Combretaceae). Roughly, we obtained similar results to those reported by van Sauers-Muller for Suriname [12]. This fly species is a serious pest of star fruits, which can be attacked at a very young stage with high fly populations. The carambola fruit fly is also a pest of Myrtaceous crops such as Malay apple and Java apple. If we compare the hosts of carambola fruit fly in Asia and Suriname some differences can be found. In Southeast Asia, 79 fruit species belonging to 27 plant families were recorded [29, 30] compared with 19 fruit species belonging to 9 plant families in Suriname [12]. Myrtaceae and Oxalidaceae fruits originating from South Asia were the highest infested species (annex III), which is not really surprising.
Anastrepha striata was found in 12 fruit species belonging to 5 families (annex III). Its main host was Psidium guajava, with an average of $143 \mathrm{fly}$ adults per $\mathrm{kg}$ fruit, followed by Spondias mombin with 37 , Syzygium malaccense with 29, Averrhoa carambola with 19 and Spondias purpurea with 7 fly adults per kg fruit. Anastrepha striata is a serious pest of guavas; it can attack fruit at very young stages (i.e., small green fruits).

Anastrepha obliqua (commonly known as the West Indian fruit fly or also the mango fruit fly) was found in 9 fruit species belonging to 4 families (annex III). Its main host was Spondias mombin, with an average of 29 fly adults per $\mathrm{kg}$ fruit, followed by Syzygium malaccense with 27 , Spondias purpurea with 12 and Syzygium samaragense with 6 fly adults per kg fruit. Interestingly, Anastrepha obliqua was not found in grafted mangoes in our study and only emerged from non-grafted ones.

Anastrepha serpentina (commonly known as the Sapote fruit fly) was found in 3 fruit species belonging to 1 family (annex III). Its main host was Chrysophyllum cainito L. (Sapotaceae), with an average of 35 fly adults per kg fruit, followed by Manilkara sapota (L.) P. Royen (Sapotaceae) with 16 fly adults per kg fruit. Anastrepha serpentina is indeed associated with the Sapotaceae family.

In five plant families, five species were established as being natural hosts (annex II) of six Anastrepha species, namely, $A$. obliqua ex Bellucia grossularioides (L.) Triana (Melastomataceae), A. leptozona ex Pouterai caimito Radlk (Sapotaceae), A. fraterculus ex Bellucia grossularioides, $A$. coronilli ex Chrysophyllum cuneifolium (Rudge) A. DC. (Sapotaceae) and Bellucia grossularioides, A. distincta ex Inga sp. (Mimosaceae) and A. sagitata ex Caryocar sp. (Caryocaraceae). Too little attention has been paid in surveys to wild native plants, especially those with small fruits and also immature fruits [31]. This issue must be taken into consideration for future ecological studies. French Guiana can provide previously unknown insect-plant relationships. 
Bactrocera carambolae, Anastrepha striata and $A$. obliqua were found in three species of Myrtaceae (Psidium guajava, Syzygium malaccense and S. samaragense) and three species of Anacardiaceae (Spondias mombin, S. purpurea and Mangifera indica), which are cultivated fruit trees. One species of Oxalidaceae hosted the carambola fruit fly and Anastrepha striata (annex III).

Over $98 \%$ of emerged adults from the star fruit (Averrboa carambola) were Bactrocera carambolae, while over $90 \%$ of emerged adults from guava (Psidium guajava) were Anastrepha striata (annex IV). Over 95\% of emerged adults from ambarella (Spondias dulcis) were B. carambolae. A few specimens of Anastrephafraterculus, $A$. antunesi and $A$. distincta were obtained from $P$. guajava. We did not differentiate the cultivars of $P$. guajava.

The fraterculus species group was associated with some plant families belonging to the plant group Rosid such as Anacardiaceae, Melastomataceae, Mimosaceae and Myrtaceae [32], as already recorded in Brazil [21]. Anastrepha serpentina seems to be associated with hosts of the family Sapotaceae (annex III). Anastrepha distincta was associated with at least one Inga species, this plant family probably being its primary host [4].

Generally, in Central and South American orchards, the predominant Anastrepha species were (60-90\%) polyphagous (i.e., A striata, A. obliqua, A. serpentina, $A$. fraterculus) [4, 33]; however, these two last species were only recorded on three hosts in French Guiana. Accurate studies in French Guiana could provide many other hosts for A. fraterculus. In Brazil, Anastrepha fraterculus attacks different families of fruit species with more than 80 host species ${ }^{1}$. These differences in host range between several geographical (Central vs. South) populations of $A$. fraterculus could be explained

\footnotetext{
${ }^{1}$ Zucchi R.A., Fruit flies in Brazil: Anastrepha species, their host plants and parasitoids, Available in: www.lea.esalq.usp.br/ anastrepha/, updated on August 10, 2011, accessed on April 12, 2012.
}

by taxonomic differences. Nevertheless, polyphagous species were not found exploiting hosts of monophagous species such as Anastrepha manihoti or Anastrepha sagitata [34].

No tephritids were obtained from these sixteen plant species: Annona reticulata L., Aniba rosaedora Ducke, Averrhoa bilimbi L., Artocarpus heterophyllus Lam., Citrus aurantifolia Sw., Citrus limon L., Citrus maxima L., Coffea canephora Pierre ex A. Froehner (= Coffea robusta), Musa sapientum L., Nephelium lappaceum L., Passiflora quadrangularis L, Persea americana Mill., Ricinus communis L., Tamarindus indica L., Theobroma cacao L. and Theobroma grandiflorum $\mathrm{L}$.

\subsection{Fruit infestation rates}

The levels of fruit infestation were very variable and ranged from 0 to 184 adults of Bactrocera carambolae per $\mathrm{kg}$ of sampled fruits; from 0 to 143 adults of Anastrepha striata per $\mathrm{kg}$ of sampled fruits; from 0 to 29 adults of $A$. obliqua per $\mathrm{kg}$ of sampled fruits; and from 0 to 35 adults of $A$. serpentina per $\mathrm{kg}$ of sampled fruits (annex III). For the two main fruit fly species, yearly averages (of 5 years) gave us 197 adults of B. carambolae from Averrboa carambola and 131 adults of $A$. striata from Psidium guajava (annex IV). If compared with the data reported by Silva et al. in a neighboring area (Amapa state, Brazil) [6], the infestation rates recorded in guava were somewhat lower in French Guiana than in Amapa; but our results are not really different from results recorded from southern states of Brazil [35].

The mean infestation rates of seven major fruit crops during 1996 were published in an undergraduate thesis [8] (figure $2)$. Eight years later, we calculated the infestation rates of these same host fruits (figure 3). No major differences were noticed except for Syzygium malaccense, where Anastrepha obliqua was not as abundant in 2003 as in 1996. This fruit fly species was predominant on $S$. malaccense both in 1993 and 2003 (figure 2, 3), although in 2003 its abundance was relatively lower. It is interesting to note that the invasive carambola 


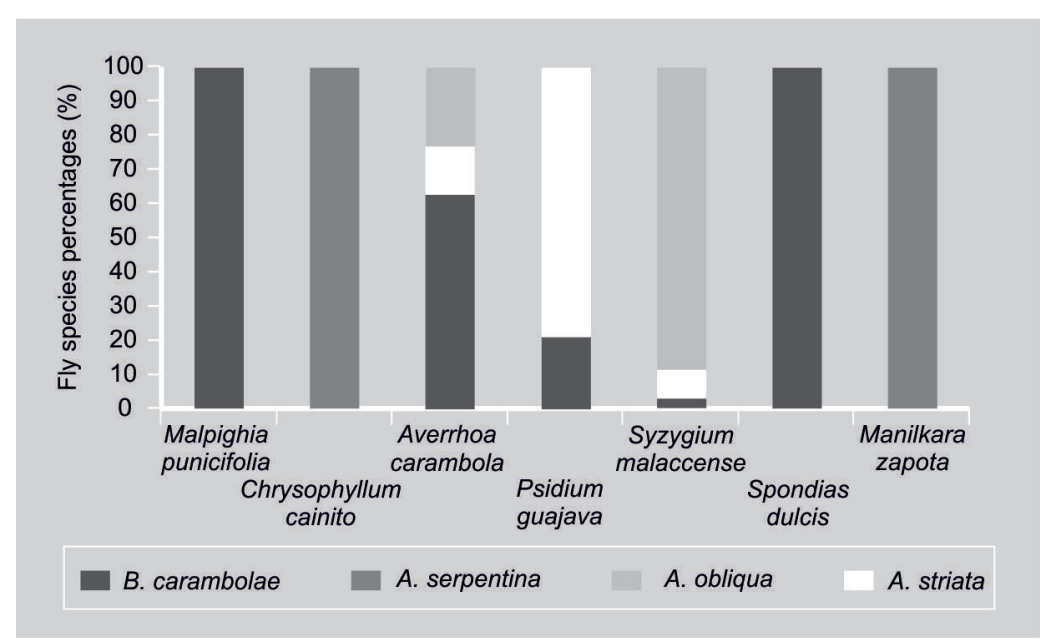

Figure 2.

Averages of fruit infestation rates by four main fruit fly species in French Guiana (data 1996).

\section{Figure 3.}

Averages of fruit infestation rates by four main fruit fly species in French Guiana (data 2003).

fruit fly was largely dominant in four hosts (Averrhoa carambola, Malpighia punicifolia, Spondias dulcis and Syzygium samarangense) (figure 3), while in the earlier study, native fruit fly species in the genus Anastrepha predominated in these host species. This only provides very indirect evidence of displacement, as there could be many other explanations. There are several recent examples of such competitive displacements among fruit flies. In Sub-Saharan Africa, another species of Bactrocera (Bactrocera invadens Drew Tsuruta \& White) has invaded and dominated several species of the genus Ceratitis in Kenya [36], Benin [37] and Senegal [38]. Other examples of competitive displacements (Bactrocera vs. Ceratitis) include well-documented cases in Reunion [39] and the Hawaiian

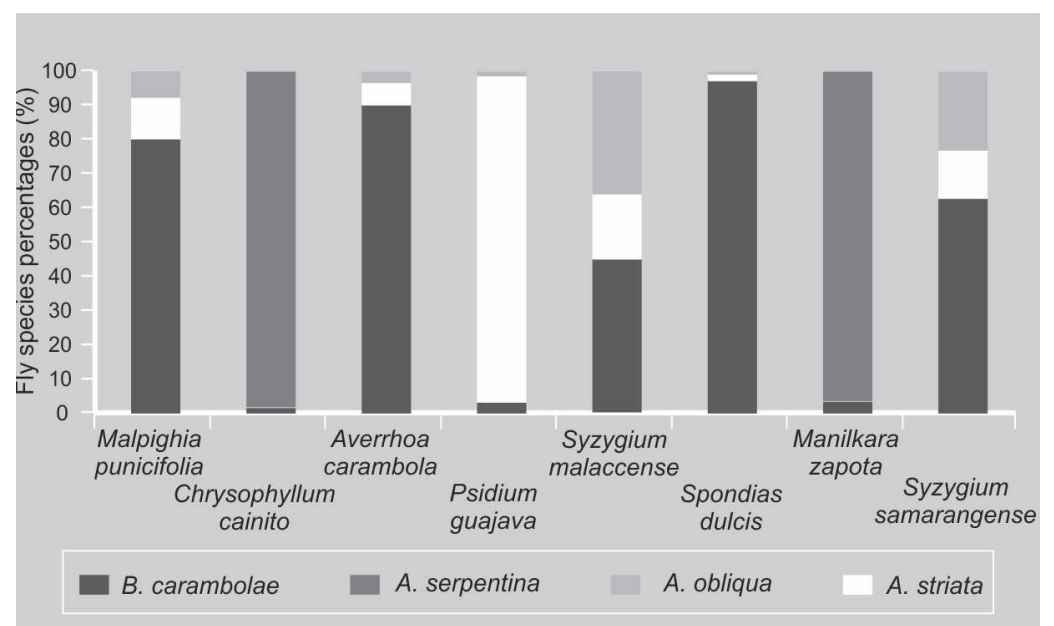

islands [40]. According to Duyck et al. [41], complete exclusion of dominated fly species usually did not occur.

Furthermore, wild fruit species were not found to be infested by the carambola fruit fly during this period in French Guiana [42]. This is important to highlight because, since 2005-2006, wild hosts from the rainforest were collected and provided a few adults of Bactrocera carambolae. In Asia, Iwahashi indicated that B. carambolae was evolving towards an adaptation of the length of its aculeus susceptible to fit with oviposition inside wild hosts of the Asian rainforest [ 43 , $44]$. The same phenomenon could be occurring in the rainforests of the north of South America. It is important to continue to monitor the possibility of carambola fruit fly adapting to native South American fruit species as hosts. Further investigation in wild hosts is warranted.

\subsection{Parasitoid species}

We recorded five species of parasitoids: Diachasmimorphalongicaudata (Ashmead) (Hymenoptera, Braconidae), Doryctobracton areolatus (Szépligeti) (Hymenoptera, Braconidae), Opius bellus Gahan (Hymenoptera, Braconidae), Utetes anastrephae (Viereck) (Hymenoptera, Braconidae) and Aganapsis pelleranoi (Brèthes) (Hymenoptera, Eucoilidae) (annex V). The first Braconidae species is exotic and was introduced into French Guiana in collaboration with EMBRAPA in 2000 and 2001 in the framework of a classical biological control program focused on Bactrocera carambolae. The last four parasitoids are native species which were already recorded in South America [6, 45]. From 2001 to 2003, the most common parasitoid species was $D$. areolatus (88\%) followed by D. longicaudata (5\%), O. bellus (3\%), A. pelleranoi (3\%) and U. anastrephae (1\%). Doryctobracton areolatus and Diachasmimorpha longicaudata accounted for $88 \%$ and $3 \%$ of the total number of parasitoids recovered in the study area (from Macouria to the Brazilian border) in 2002, and $87 \%$ and $6 \%$ in 2003, respectively. Doryctobracton areolatus was also the predominant species in several other studies in Brazil [46] and also in Argentina [47]. This predominance could 
be the result of several reasons: (i) higher foraging efficiency; (ii) a wider host breadth; (iii) intra-larval competition; (iv) higher efficiency in suppressing immune response in the host larvae; (v) no clear evidence of host plant preference [45], etc.

No native parasitoid species emerged from samples of Bactrocera carambolae in French Guiana during the period 20012003. However, we cannot have evidence that the local parasitoids have evolved the ability or not to detect and attack immature stages of this new invasive species. If they can attack, they can also fail to develop due to low host suitability or a strong response of the host immune system. According to our observations, only Diachasmimorpha longicaudata emerged from pupae of the carambola fruit fly. Our massive releases of $D$. longicaudata, with several millions of adults in 2000 in collaboration with EMBRAPA along the river Oyapock, targeted in fact both Anastrepha spp. and B. carambolae (annex $V$ ). This point is important in relation to future programs of biological control activities. The percent of parasitism rate was also variable and ranged from $0 \%$ to $14.3 \%$.

The most frequent species was Doryctobracton areolatus, followed by Diachasmimorpha longicaudata, only recorded along the Brazilian border (along the Oyapock river), where the releases were carried out in 2000. Parasitoids were found infesting tephritid larvae associated with ten host species (annex $V$ ). Fruit size influences parasitism rates by parasitoids, as these insects parasitize larvae inside the fruit using their ovipositor. Larvae that are deep inside larger fruits seem to escape parasitism by braconids [48]. Apart the fact that pupae from different fly species were kept under the same environmental conditions, we must stress the following remark: when fruit is sampled from the field, it is inevitably out of reach for late-instar larval parasitoids. So, we can also say that this could have led to an underestimation of $D$. longicaudata abundance. Nowadays, D. longicaudata is established in French Guiana. It has surely affected the assembly of local species but was ineffective in controlling fruit flies.

Most published information on Anastrepha host-plant relationships with parasitoid associations has been summarized by Leonel et al. [49], Zucchi [50, 51], Norrbom [18], Aluja et al. [34], Ovruski et al. [45], De Jesus et al. [52], Schliserman et al. [53], Silva et al. [6] and Bittencourt et al. [54]. There is a large guild of native parasitoids existing in South America and our four native species are already mentioned. The average of tephritid parasitism was very low in the East and center of French Guiana [42], with 2\%, and a little higher $(3.5 \%)$ on the Brazilian border. These preliminary results could support introductions of exotic braconid species as potential biological control agents.

During our 3-year study (2001-2003), we did not observe any seasonality in either fruit fly-host associations or fruit fly-parasitoid associations. One of the reasons could be the several seasons of fruit production throughout the year.

\subsection{Perspectives of fruit fly control in French Guiana}

According to our previous experience in fruit fly management in French Guiana, it seems relevant to underline the following traits.

Bactrocera carambolae is the main target among fly species of economic significance; however, several species of Anastrepha also cause threats to three families (Myrtaceae, Anacardiaceae and Sapotaceae) in French Guiana. The combined and coordinated management of both carambola fruit fly and Anastrepha spp. is necessary in order to (i) support national growers who have recently diversified and also developed fruit productions in French Guiana; (ii) participate with efficiency in a revival of a regional effort targeted on carambola fruit fly control with Brazil and Suriname; (iii) develop some potential exports of fruit production, and (iv) detect an eventual introduction of Ceratitis capitata or other Bactrocera species into this region.

Many extrapolations were made for the carambola fruit fly in the North of South America from many studies and control activities of Bactrocera dorsalis from Southeast Asia. Accurate biological and ecological data are needed for the carambola 
fruit fly, specifically for the biotype existing in northern South America. It is quite relevant that some biological (demographic parameters, beginning of sexual maturity), ecological (host array including wild hosts, long-term response to methyl eugenol) and behavioral studies (aptitude for dispersion, interspecific competition) should have been done before launching a new large control program against the carambola fruit fly.

Carambola fruit fly and Anastrepha control in French Guiana could be managed with an IPM Package including the Male Annihilation Technique (MAT) [55] and also classical biological control. The MAT (with methyl eugenol and insecticide) will be used with Bactrogel sprays which are largely more efficient, quicker, cheaper and require less human resources. The MAT has worked very well with block methods [9, 11]. Furthermore, we demonstrated that blocks with methyl eugenol and insecticide can be used in an area-wide program without risk to non-target insect populations [56]. It is an important result when working in primary rainforest with high biodiversity indices like in French Guiana.

Laboratory tests with the carambola fruit fly and several Anastrepha species of economic interest should be carried out to evaluate the effectiveness of Diachasmimorpha longicaudata. Likewise, the potential of Fopius arisanus Sonan should be assessed. Considering that this parasitoid is being successfully used in Central America [57] and South America [58] to control Anastrepha species and also that this species was able to establish along the Brazilian border and in fruit sampling (2001-2003), biological control activities should be developed with D. longicaudata against Anastrepha spp. Considering that D. longicaudata is currently used in Central America [57] and South America [58] vs. Anastrepha species, according to both the previous releases along the Brazilian border and our fruit sampling (2001-2003), this braconid species could be effective against these native fly species in French Guiana. We recorded that D. longicaudata can also attack immature stages of the carambola fruit fly (annex $V$ ). Thus, releases of $D$. longicaudata could be extended to the whole of French Guiana.
Taking into consideration the promising results of Fopius arisanus against Bactrocera dorsalis in South Asia, Hawaii and the Polynesian Islands [59], it seems relevant to propose massive releases of this Braconidae species against Bactrocera carambolae in zones without the MAT. Each introduction into a new area should be followed by studies of (i) its acclimation; (ii) its dispersion, and (iii) its impact on fruit fly populations. This research phase would allow us to collect information necessary to validate our protocols towards transfer of technology afterwards.

\section{Conclusion}

Our preliminary study proved to be fruitful in gaining insight into ecological patterns such as host-parasitoid associations and fruit fly life strategies. More thorough studies focused on the ecology of polyphagous species (both in orchards and in rainforests) might help in understanding the factors that could transform some tephritid species into major pests of cultivated fruits. Further studies should be carried out in French Guiana, including areas of primarily native vegetation. Considering the high number of plant species, we should expect to discover a large number of new Anastrepha species through continued sampling in the rainforest and environments which were not prospected. French Guiana and, to a great extent, the "Guyana plateau", is considered a rich biome which harbors a high level of endemism, high species richness and localities of diversity of plant families that could provide very interesting results of interactions between insects and plants [60, 61]. Given the rapidity of the habitat destruction of rainforests (with the leading case of species extinction), serious conservation efforts of the Guyanese forests are very necessary.

\section{Acknowledgements}

We would like to thank all the staff of FDGPC (Cayenne), SPV (Cayenne), DAF (Cayenne), CNES (Cayenne) and CIRAD 
(Kourou), namely, Fernand Boyer, Mathieu Chambaud, Michel Blanc and Pierre Cremoux, the growers André Carrobourg and André Kindou from French Guiana, all the Brazilian team (from Oyapoque, Macapa, Bahia, Sao Paulo, Brazilia) and also the French Ministry of Foreign Affairs (Paris). The authors are indebted to Romulo Carvalho (EMBRAPA), Jorge A. Guimaraes (EMBRAPA), Ian White (BNHM) and Gérard Delvare (CIRAD), who provided some fruit fly and parasitoid identifications

\section{References}

[1] Aluja M., Bionomics and management of Anastrepha, Annu. Rev. Entomol. 39 (1994) 155-178.

[2] Zucchi R.A., A catalogue of the Anastrepha species (Diptera: Tephritidae), their host plants and braconid parasitoids in Brazil, in: Tan K.H. (Ed.), 5th Int. Symp. on Fruit flies of economic importance, Abstracts, IAEA Penang, Malays., 1998.

[3] Malavasi A., Zucchi R.A., Sugayama R.L., Biogeographia, in: Malavasi A., Zucchi R.A. (Eds.), Mosca-das-frutas de importancia economica no Brazil: conhecimento basico e applicado, Holos Ed., Ribeirao Preto, Brazil, 2000, pp. 93-98.

[4] Norrbom A.L., Host plant database for Anastrepha and Toxotrypana (Diptera: Tephritidae: Toxotrypanini), in: Norrbom A.L., Thompson F.C. (Eds.), Diptera Data dissemination disk (CD-Rom) 2, USDA, Wash., U.S.A., 2004.

[5] Segura D.F., Vera M.T., Cagnotti C.L., Vaccaro N., De Coll O., Ovruski S.M., Cladera J.L., Relative abundance of Ceratitis capitata and Anastrepha fraterculus (Diptera: Tephritidae) in diverse hosts species and localities of Argentina, Ann. Entomol. Soc. Am. 99 (2006) 70-83.

[6] Silva R.A., Lima A.L., Xavier S.L., Silva W.R., Marinho C.F., Zucchi R.A., Anastrepha species (Diptera: Tephritidae), their hosts and parasitoids in southern Amapa state, Brazil, Biota Neotropical 11 (2011) 429-434.

[7] Caplong P., Étude de faisabilité d'un programme d'éradication de la mouche de la carambole en Guyane française, Féd. Dép. Group. Prot. Cult. Guyane, Rapp. Synth., janv. 1994-sept. 1995, POSEIDOM, Cayenne, Guyane Fr., 1995.

[8] Séguret J., Les mouches des fruits de Guyane française : inventaire des principales espèces et recherche d'un attractif efficace, ENSAM, Mém., Montpellier, Fr., 1996.

[9] Malavasi A., Sauers-Muller van A.E., Midgarden D., Kellman V., DidelotD., Caplong P., Ribeiro O., Regional program for the eradication of the carambola fruit fly in South America, in: Tan E.K. (Ed.), 5th Int. Symp. on Fruit flies of economic importance, IAEA, Penang, Malays., 1998, pp. 395-399.

[10] Cayol J.-P., Rapport d'activités, Doc. Int., CIRAD-DAF, Cayenne, Guyane Fr., 1999.

[11] Vayssières J.-F., Rapports annuels de lutte contre les mouches des fruits en Guyane française, Doc. Int., CIRAD, station de Kourou, Guyane Fr., 2001-2003.

[12] Sauers-Muller van A.E., Host plants of the carambola fruit fly, Bactrocera carambolae Drew \& Hancock (Diptera: Tephritidae), in Suriname, South America, Neotropical Entomol. 34 (2005) 203-214.

[13] Norrbom A.L., Zucchi R.A., Hernández-Ortiz V., Phylogeny of the genera Anastrepha and Toxotrypana(Trypetinae:Toxotrypanini) based on morphology, in: Aluja M., Norrbom A.L. (Eds.), Fruit Flies (Tephritidae): Phylogeny and evolution of behaviour, CRC Press, Boca Raton, Fla., U.S.A., 1999.

[14] Malavasi A., Zucchi R.A., Mosca-das-frutas de importancia economica no Brazil: conhecimento basico e applicado, Holos Ed., Ribeirao Preto, Brazil, 2000.

[15] Norrbom A.L., Foote R.H., The taxonomy and zoogeography of the genus Anastrepha (Diptera: Tephritidae), in: Robinson A.S., Hooper G. (Eds), Fruit flies: their biology, natural enemies and control, World Crop Pest, vol. 3A, Elsevier Sci., N.Y., U.S.A., 1989, 15-26.

[16] Zucchi R.A., A new species of fruit fly in the genus Anastrepha Schiner, 1868 (Diptera: Tephritidae) from Brazil, Ann. Soc. Entomol. Bras. 11 (1982) 251-254.

[17] Uramoto K., Zucchi R.A., New species in the genus Anastrepha (Diptera: Tephritidae) from Brazil, Ann. Soc. Entomol. Bras. 28 (1999) 85-89.

[18] Norrbom A.L., Caraballo J., A new species of Anastrepha from Amazonia with redescriptions of $A$. caudata Stone and $A$. hendeliana Lima (Diptera: Tephritidae), Insecta Mundi 17 (2003) 33-43. 
[19] Norrbom A.L., Korytkowsky C.A., New species of and taxonomic notes on Anastrepha (Diptera: Tephritidae), Zootaxa 2740 (2011) 1-23.

[20] Aluja M., Díaz-Fleischer F., Foraging behavior of Anastrepha ludens, $A$. obliqua and $A$. serpentina in response to feces extracts containing host marking pheromone, J. Chem. Ecol. 32 (2006) 367-389.

[21] Uramoto K., Martins D.S., Zucchi R.A., Fruit flies (Diptera: Tephritidae) and their associations with native host plants in a remnant area of the highly endangered atlantic rain forest in the state of Esperito Santo, Brazil, Bull. Entomol. Res. 98 (2008) 457-466.

[22] Sauers-Muller van A.E., An overview of the carambola fruit fly, Bactrocera species (Diptera: Tephritidae), found recently in Suriname, Fla. Entomol. 74 (1991) 432-440.

[23] Sauers-Muller van A.E., Annual reports of the carambola fruit fly project, Agric. Exp. Stn., Paramaribo, Suriname, 1990-2002.

[24] McPheron B.A., Han H.Y., Silva J.G., Norrbom A.L., Phylogeny of the genera Anastrepha and Toxotrypana (Trypetinae: Toxotrypanini) based upon 16srRNA mitochondrial DNA sequences, in: Aluja M., Norrbom A.L. (Eds.), Fruit flies (Tephritidae): Phylogeny and evolution of behavior, CRC Press, Boca Raton, Fla., U.S.A., 1999, pp. 343-361.

[25] Caceres C., Segura D.F., Vera M.T., Wornoayporn V., Cladera J.L., Teal P., Sapountzis P., Bourtzis K., Zacharopoulou A., Robinson A.S., Incipient speciation revealed in Anastrepha fraterculus (Diptera: Tephritidae) by studies on mating compatibility, sex pheromones, hybridization and cytology, Biol. J. Linn. Soc. 97 (2009) 152-165.

[26] Segura D.F., Vera M.T., Rull J., Wornoayporn V., Islam A., Robinson A.S., Assortative mating among Anastrepha fraterculus (Diptera: Tephritidae) hybrids as a possible route to radiation of the fraterculus cryptic species complex, Biol. J. Linn. Soc. 102 (2011) 346354.

[27] Drew R.A.I., Hancock D.L., The Bactrocera dorsalis complex of fruit flies (Diptera: Tephritidae: Dacinae) in Asia, Bull. Entomol. Res. Suppl. 2 (1994) 1-68.

[28] Norrbom, A.L., A revision of the Anastrepha serpentina species group (Diptera: Tephritidae), Proc. Entomol. Soc. Wash. 104 (2002) 390-436.

[29] White I.M., Elson-Harris M.M., Fruit flies of economic significance: their identification and bionomics, CAB Int., Wallingford, U.K., 1992.
[30] Alwood A.J., Chinajariyawong A., Kritsaneepaiboon S., Drew R.A.I., Hamacek E.L., Hancock D.L., Hengsawad C., Jipanin J.C., Jirasurat M., Kong Krong C., Leong C.T.S., Vijaysegaran S., Host plant records for fruit flies (Diptera: Tephritidae) in Southeast Asia, Raffles Bull. Zool. 7 (1999) 1-92.

[31] Aluja M., Pinero I., Jacome F., Diaz-Fleischer F., Sivinski J., Behavior of flies in the genus Anastrepha (Trypetinae: Toxotrypanini), in: Aluja M., Norrbom A.L. (Eds.), Fruit flies (Tephritidae): Phylogeny and evolution of behavior, CRC Press, Boca Raton, Fla., U.S.A., 1999, 375-406.

[32] Judd W.S., Campbell C.S., Kellog E.A., Stevens P.F., Donoghue M.J., Plant systematics: a phylogenetic approach, 2nd ed., Sinauer Assoc., Sunderland, MA, U.S.A., 2002.

[33] Celedonio-Hurtado H., Aluja M., Liedo P., Adult population fluctuations of Anastrepha species (Diptera: Tephritidae) in tropical orchard habitats of Chiapas, Mexico, Environ. Entomol. 24 (1995) 861-869.

[34] Aluja M., Rull J., Sivinski J., Norrbom A.L., Wharton R.A., Macias-Ordonez R., DiazFleischer F., Lopez M., Fruit flies of the genus Anastrepha (Diptera: Tephritidae) and associated native parasitoids (Hymenoptera) in the tropical rain forest biosphere reserve of montes Azules, Chiapas, Mexico, Environ. Entomol. 32 (2003) 1377-1385.

[35] Zucchi R.A., Diversidad, distribución y hospederos del genero Anastrepha en Brasil, in: Hernández-Ortiz V. (Ed.), Moscas de la fruta en Latino América (Diptera: Tephritidae): diversidad, biología y manejo, S. y G. Ed., Mexico, D.F., 2007.

[36] Lux S.A., Copeland R.S., White I.M., Manrakhan A., Billah M.K., A new invasive fruit fly species from the Bactrocera dorsalis (Hendel) group detected in East Africa, Insect Sci. Appl. 23 (2003) 355-361.

[37] Vayssières J.-F., Goergen G., Lokossou O., Dossa P., Akponon C., A new Bactrocera species detected in Benin among mango fruit flies (Diptera: Tephritidae) species, Fruits 60 (2005) 371-377.

[38] Vayssières J.-F., Vannière H., Gueye P.S., Barry O., Hanne A.M., Korie S., Niassy A., Ndiaye M., Delhove G., Preliminary inventory of fruit fly species (Diptera: Tephritidae) in mango orchards in the Niayes region, Senegal, in 2004, Fruits 66 (2011) 91-107.

[39] Duyck P-F., David P., Pavoine S., Quilici S., Can host-range allow niche differentiation of 
invasive fruit flies (Diptera: Tephritidae) in La Réunion? Ecol. Entomol. 33 (2008) 439-452.

[40] Reitz S.R., Trumble J.T., Competitive displacement among insects and arachnids, Annu. Rev. Entomol. 47 (2002) 435-465.

[41] Duyck P.-F., David P., Quilici S., A review of relationships between interspecific competition and invasions in fruit flies (Diptera: Tephritidae), Ecol. Entomol. 29 (2004) 511520.

[42] Vayssières J.-F., Cayol J.-P., Chambaud M., Blanc M., Degré d'infestation de différentes espèces fruitières par les Tephritidae en Guyane française et pourcentage de parasitisme des espèces de Tephritidae d'intérêt économique, in: XIV Colloque Physiol. Insecte, Univ. Picardie J. Verne, Amiens, Fr., 2003, PP. 11-18.

[43] Iwahashi O., Distinguishing between the two sympatric species Bactrocera carambolae and B. papayae (Diptera: Tephritidae) based on aedeagal length, Ann. Entom. Soc. Am. 92 (1999) 1-5.

[44] Iwahashi O., Speciation of Bactrocera dorsalis complex based on aedeagal length, In: K.H. Tan (Ed.), Area-wide control of fruit flies and other insect pests, Penerbit Univ. Sains (Eds.), Penang, Malaysia, 2000, 591-594.

[45] Ovruski S.M., Wharton R.A., Schliserman P., Aluja M., Abundance of Anastrepha fratercuIus (Diptera: Tephritidae) and its associated native parasitoids (Hymenoptera) in "feral" guavas growing in the endangered Northern Yungas forests of Argentina with an update on the taxonomists of Opiinae parasitoids reported in this country, Environ. Entomol. 34 (2005) 807-818.

[46] Souza Filho Z.A., Araujo E.L., Guimaraes J.A., Silva J.G., Endemic parasitoids associated with Anastrepha spp. (Diptera: Tephritidae) infesting guava (Psidium guajava L.) in southern Bahia, Brazil, Fla. Entomol. 90 (2007) 783-785.

[47] Ovruski S.M., Schlisermann P., Orono L.E., Nunez-Campero S.R., Albornoz-Medina P., Bezdjian L.P., Van Nieuwenhove G.A., Natural occurrence of Hymenopterous parasitoids associated with Anastrepha fraterculus (Diptera: Tephritidae) in Myrtaceae species in Entre Rios, northeastern Argentina, Fla. Entomol. 91 (2008) 220-227.

[48] Sivinsky J., Vulinec K., Aluja M., Ovipositor length in a guild of parasitoids (Hymenoptera Braconidae) attacking Anastrepha spp. fruit flies (Diptera: Tephritidae) in southern
Mexico, Ann. Entomol. Soc. Am. 94 (2001) 886-895.

[49] Leonel F.L., Zucchi R.A., Wharton R.A., Distribution and tephritidae host (Diptera) of Braconidae parasitoids (Hymenoptera) in Brazil, Int. J. Pest Manag. 41 (1995) 363-370.

[50] Zucchi R.A., Taxonomia, in: Malavasi A., Zucchi R.A. (Eds.), Mosca-das-frutas de Importancia Economica no Brazil: conhecimento basico e applicado, Holos Ed., Ribeirao Preto, Brazil, 2000, pp. 13-24.

[51] Zucchi R.A., Especies de Anastrepha, sinonimias, plantas hospedeiras e parasitoides, in: Malavasi A., Zucchi R.A. (Eds.), Moscadas-frutas de Importancia Economica no Brazil: conhecimento basico e applicado, Holos Ed., Ribeirao Preto, Brazil, 2000, pp. 41-48.

[52] Jesus C.R., Pereira J.D.B., de Oliveira M., da Silva A., Souza Filho M.F., da Costa Neto S., Marinho C., Zucchi R.A., New records of fruit flies (Diptera: Tephritidae), wild hosts and parasitoids (Hymenoptera Braconidae) in the Brazilian Amazon, Neotropical Entomol. 37 (2008) 733-734.

[53] Schliserman P., Ovruski S.M., de Coll O.R. Wharton R., Diversity and abundance of Hymenopterous parasitoids associated with Anastrepha fraterculus (Diptera: Tephritidae) in native and exotic hosts plants in Misiones, northeastern Argentina, Fla. Entomol. 93 (2010) 175-182.

[54] Bittencourt M.A., da Silva A.C., Silva V.E., Bomfim Z.V., Guimaraes J.A., de Souza Filho M.F., Araujo E.I., Moscas das frutas (Diptera: Tephritidae) e seus parasitoides (Hymenoptera: Braconidae) associados as plantas hospedeiras no sul da Bahia, Neotropical Entomol. 40 (2011) 405-406.

[55] Malavasi A., Midgarden D., Sauers-Muller van A.E., Operations manual, Reg. Proj. Control of the Carambola fruit fly in South America, IICA, Paramaribo, Suriname, 1998.

[56] Vayssières J.-F., Cayol J.-P., Perrier X., Midgarden D., Impact of methyl eugenol and malathion bait stations on non-target insect populations in French Guiana during an eradication program for Bactrocera carambolae, Entomol. Exp. Appl. 125 (2007) 55-62.

[57] Montoya P., Liedo P., Benrey B., Cancino J., Barrera F., Sivinski J., Aluja M., Biological control of Anastrepha spp. (Diptera: Tephritidae) in mango orchards through augmentative releases of Diachasmimorpha longicaudata (Ashmead) (Hymenoptera Braconidae), Biol. Control 18 (2000) 216-224. 
[58] Carvalho R.S., Avaliaçao das liberaçoes inundativas do parasitoide exotico Diachasmimorpha longicaudata (Ashmead) (Hymenoptera: Braconidae) em pomar diversicado em Conceiçao do Almeida, BA, Neotropical Entomol. 34 (2005) 799-805.

[59] Vargas R., Leblanc L., Putoa R., Eitam A., Impact of introduction of Bactrocera dorsalis (Diptera: Tephritidae) and classical biological control releases of Fopius arisanus (Hymenoptera: Braconidae) on economically important fruit flies in French Polynesia, J. Econ. Entomol. 100 (2007) 670-679.

[60] Uramoto K., Zucchi R.A., New species of Anastrepha Schiner (Diptera: Tephritidae) from remnant area of the Atlantic rain forest and surroundings in the state of Espirito, Brazil, Zootaxa 2535 (2010) 49-60.

[61] Garcia F., Norrbom A., Tephritoid flies (Diptera: Tephritoidea) and their plant hosts from the state of Santa Catarina in Southern Brazil, Fla. Entomol. 94 (2011) 151-157.

\section{Diversidad de las especies de mosca de la fruta (Diptera: Tephritidae) pre- sentes en la Guayana Francesa: principales plantas huéspedes y parasitoi- des durante el periodo 1994-2003, y perspectivas de control.}

Resumen - Introducción. El presente estudio se desarrolló en la Guayana Francesa durante diez años (1994-2003) gracias a tres instituciones (SPV, FDGPC,CIRAD); contribuye a realizar un inventario de las especies de Tephritidae (Dacini and Toxotrypanini) presentes en dicho país. Material y métodos. Dicho inventario afecta a las zonas habitadas de la Guayana Francesa desde la frontera brasileña hasta la frontera sudamericana, concretamente a las localidades que cuentan con cultivos frutales. Las Tephritidae se obtuvieron mediante la captura de los adultos y el muestreo de las frutas alrededor de las huertas y al borde de la pluviselva. La captura duró diez años enteros, mientras que los muestreos de fruta se realizaron de manera interrumpida. Presentamos los resultados de tres años consecutivos (de 2001 a 2003), durante los cuales se recolectaron un total de $880 \mathrm{~kg}$ de fruta, con 45 especies de frutales que representaban a 22 familias. Resultados. 29 especies de frutales pertenecientes a 14 familias fueron huéspedes de 21 especies de Anastrepha y de una especie de Bactrocera, Bactrocera carambolae (Drew and Hancock). Durante este periodo no se capturó ningún especimen de Ceratitis capitata (Wiedemann), ni tampoco apareció en las frutas recolectadas. Presentamos a continuación las principales especies frutales huéspedes de B. carambolae y Anastrepha spp. Identificamos cinco especies de himenópteros parasitoides. Entre ellas, Diachasmimorpha longicaudata (Ashmead) (Hymenoptera, Braconidae) es una especie exótica introducida en la Guayana Francesa en 2000 y 2001 en colaboración con la EMBRAPA, dentro de un programa de control biológico. Conclusión. Estas observaciones preliminares pueden aportar datos fundamentales en el caso de que se retomen los programas de lucha contra B. carambolae y contra las principales especies de Anastrepha en la cuenca amazónica. Dichos resultados se analizaron teniendo en cuenta no solo su valor para la protección de las selvas primarias, sino también la evolución de las relaciones insectos-plantas.

Guayana Francesa / árboles frutales / plantas huéspedes / insectos depredadores de los frutos / colección de datos / Tephritidae / Braconidae / Bactrocera carambolae / Anastrepha 


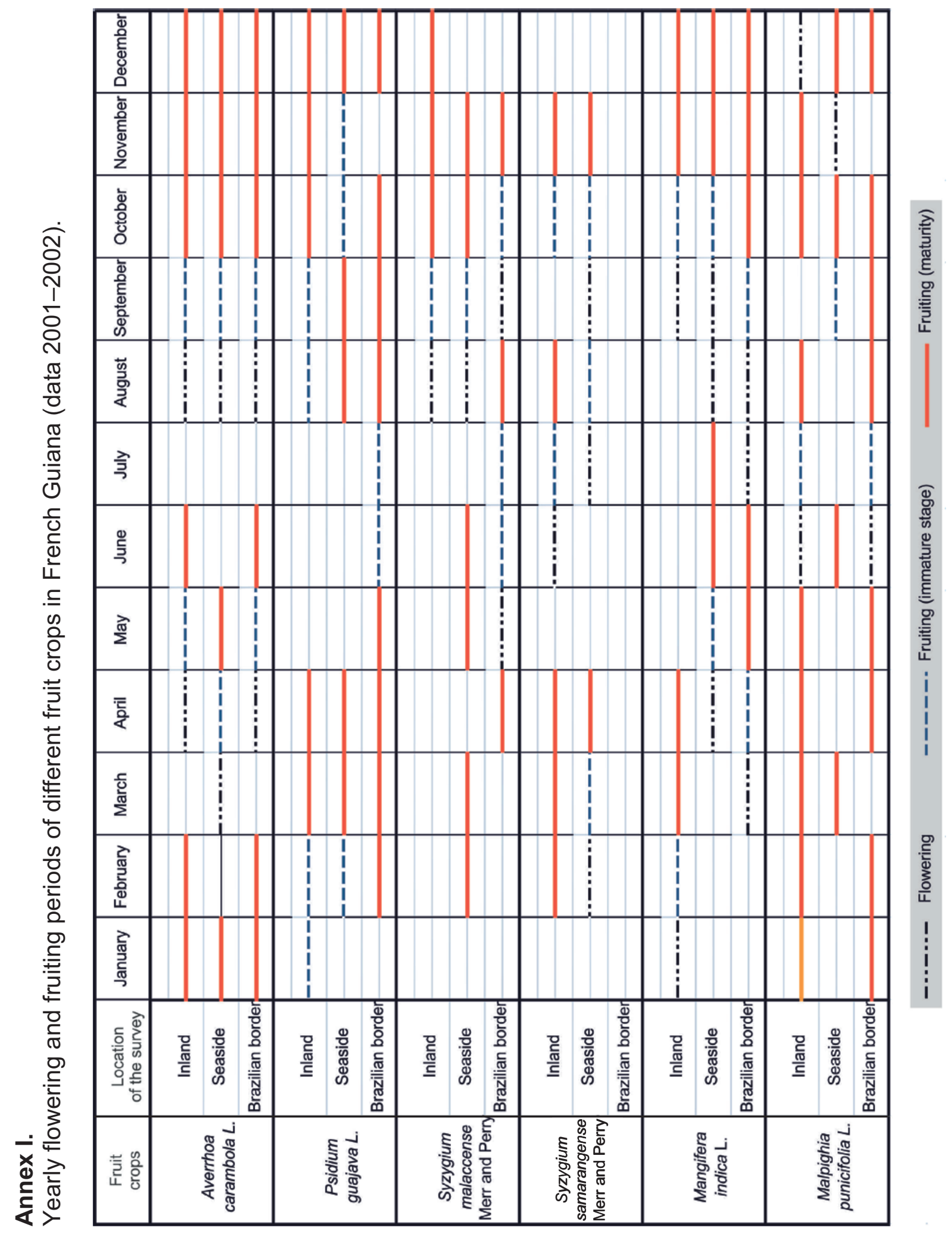




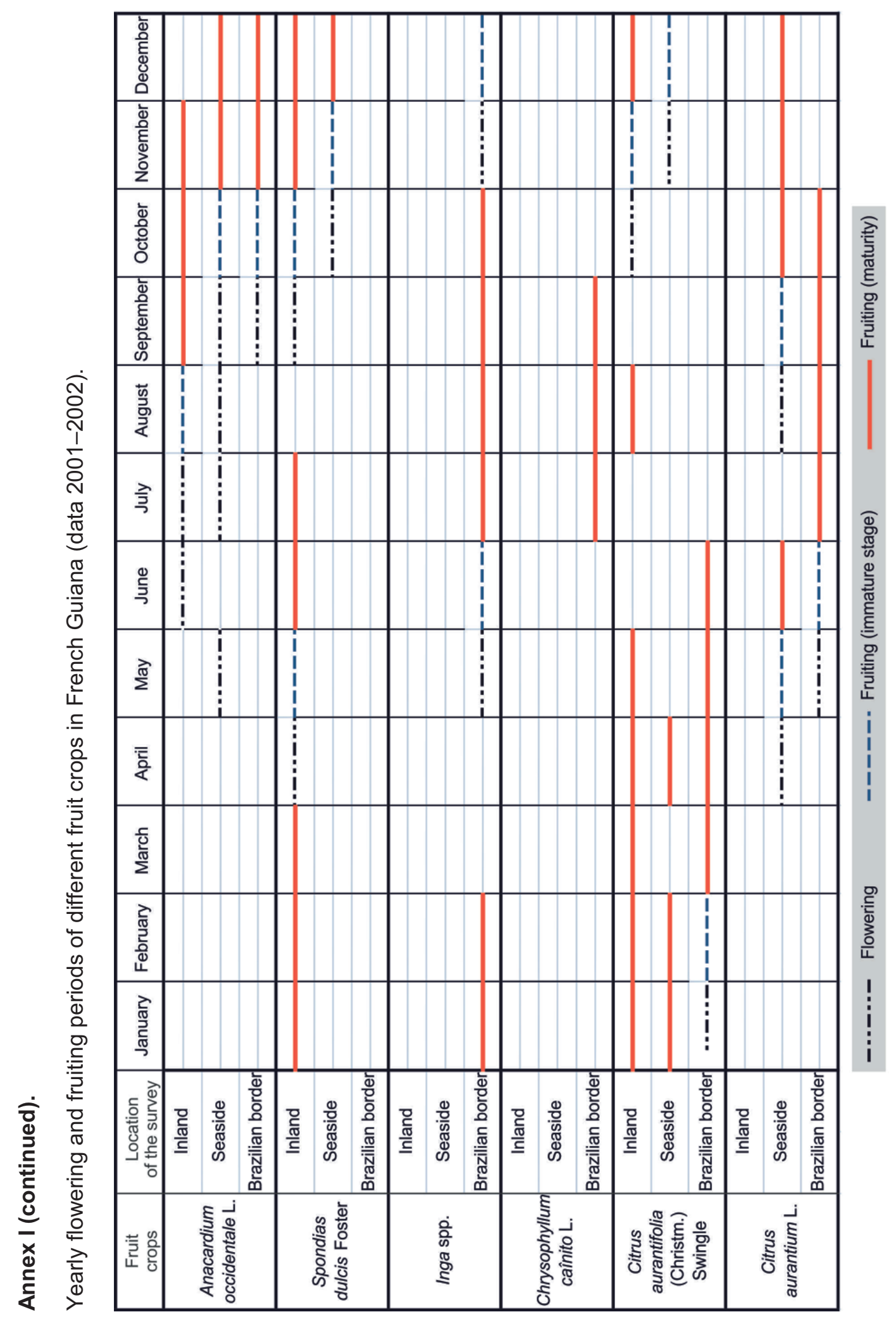


Fruit fly species from French Guiana

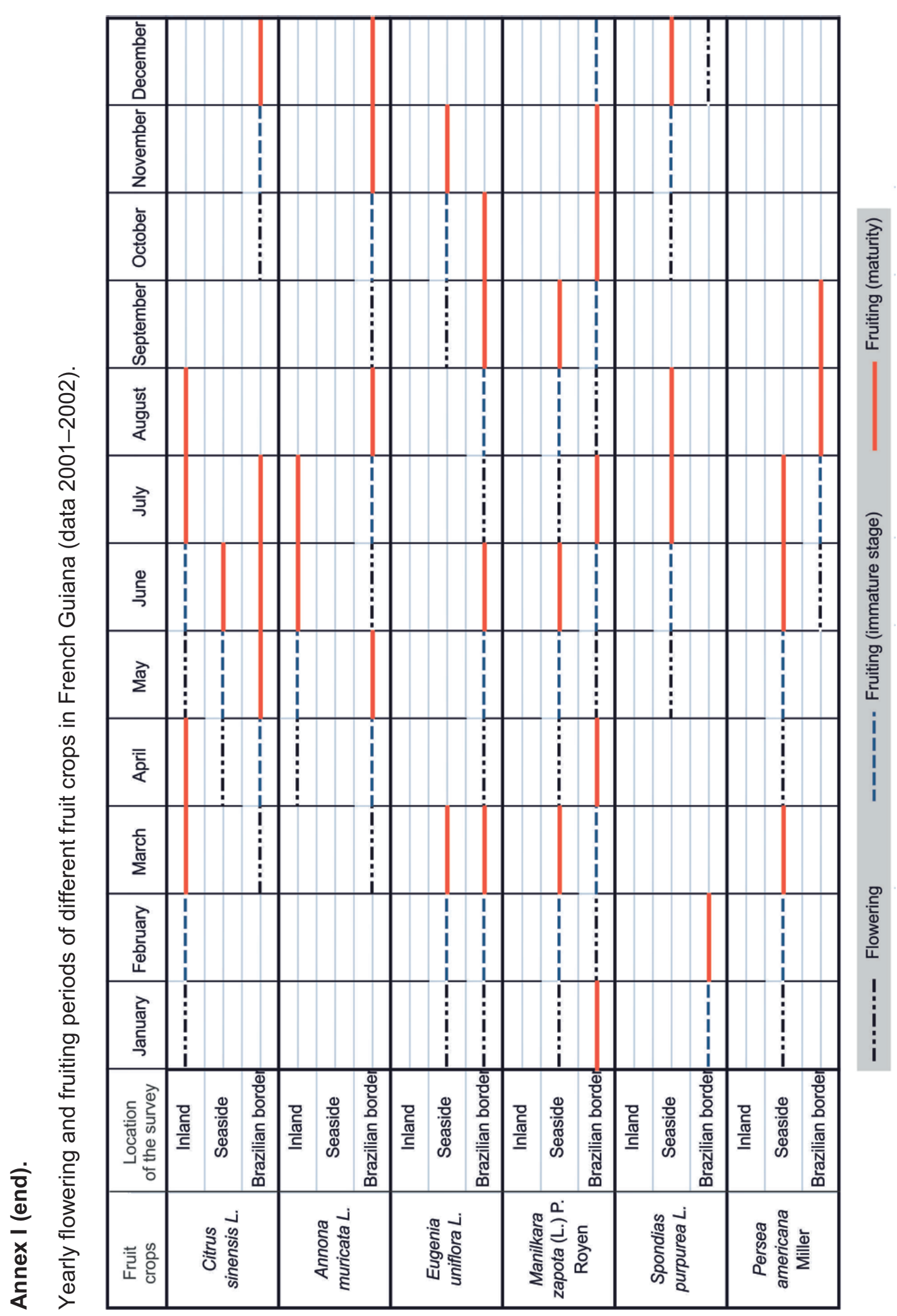




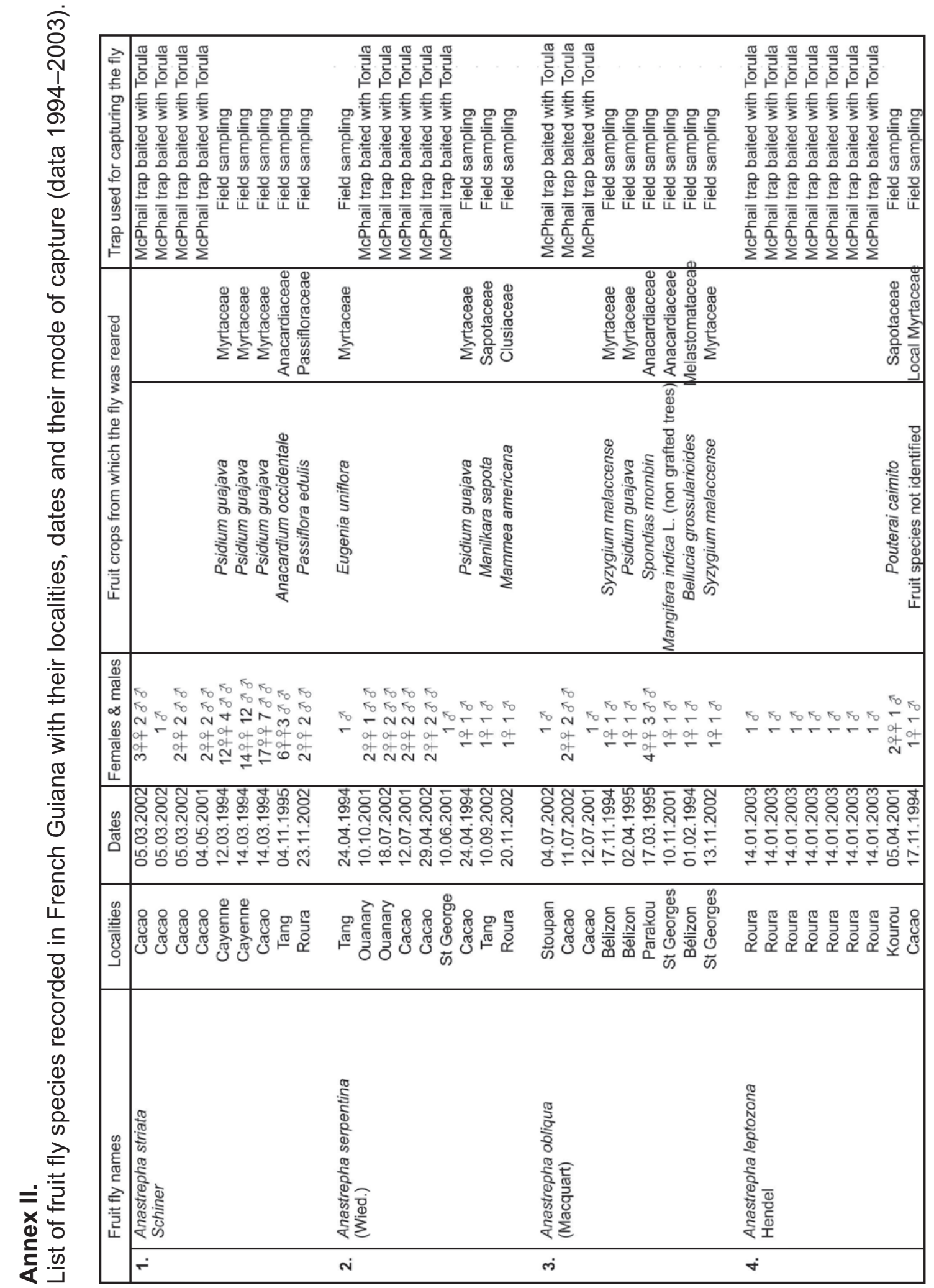


Fruit fly species from French Guiana

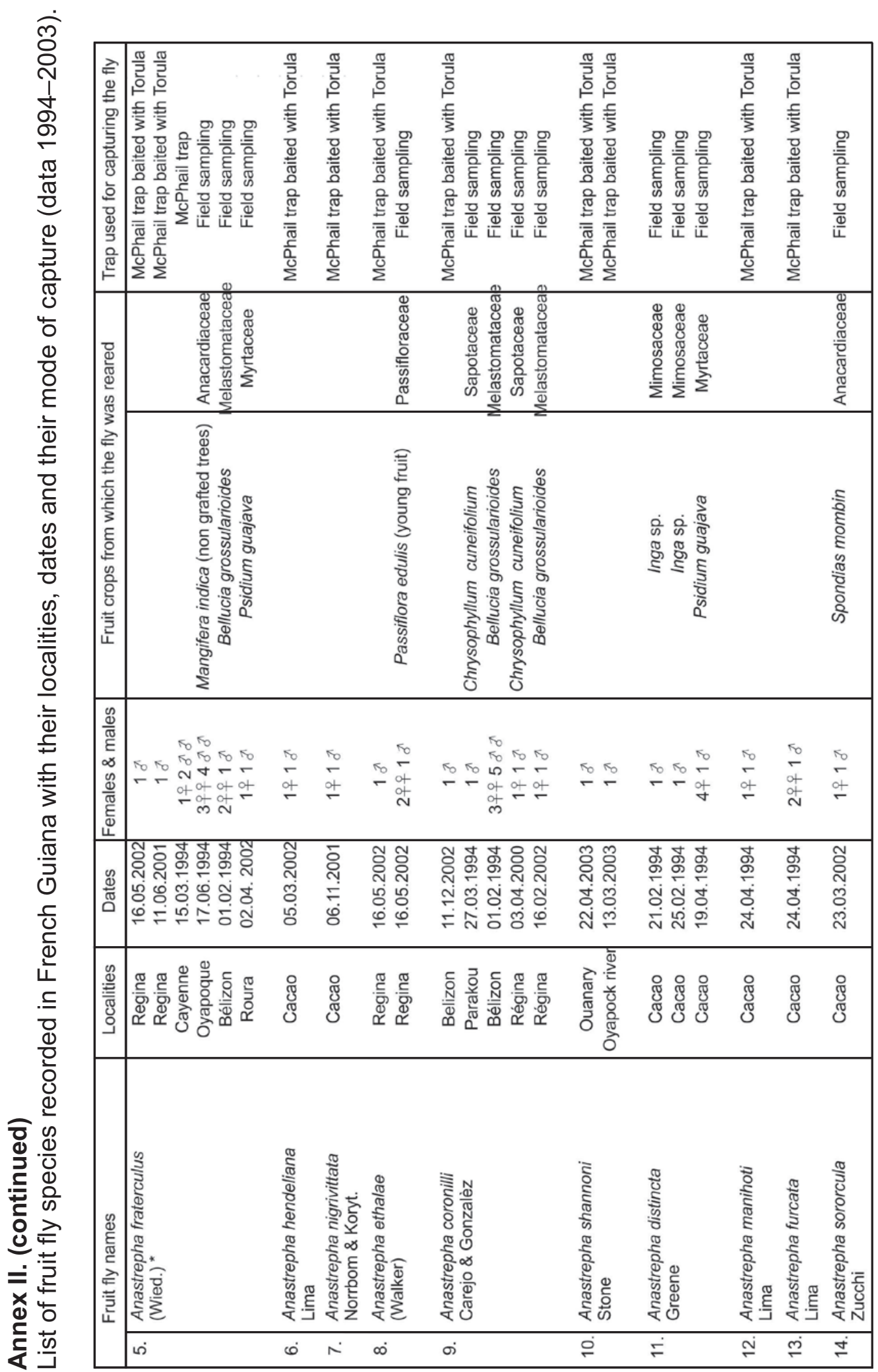

Fruits, vol. 68 (3) 239 


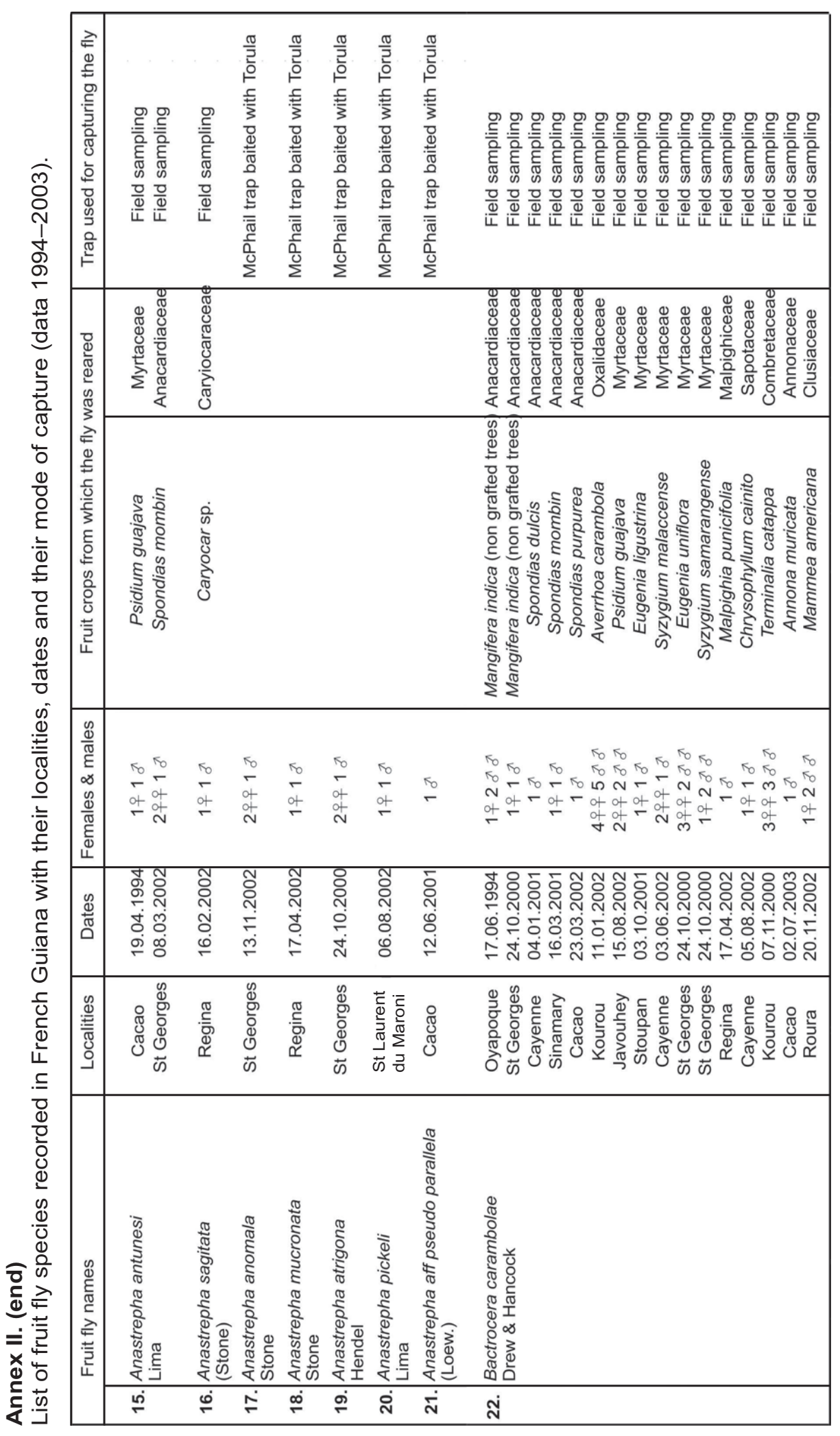


Fruit fly species from French Guiana

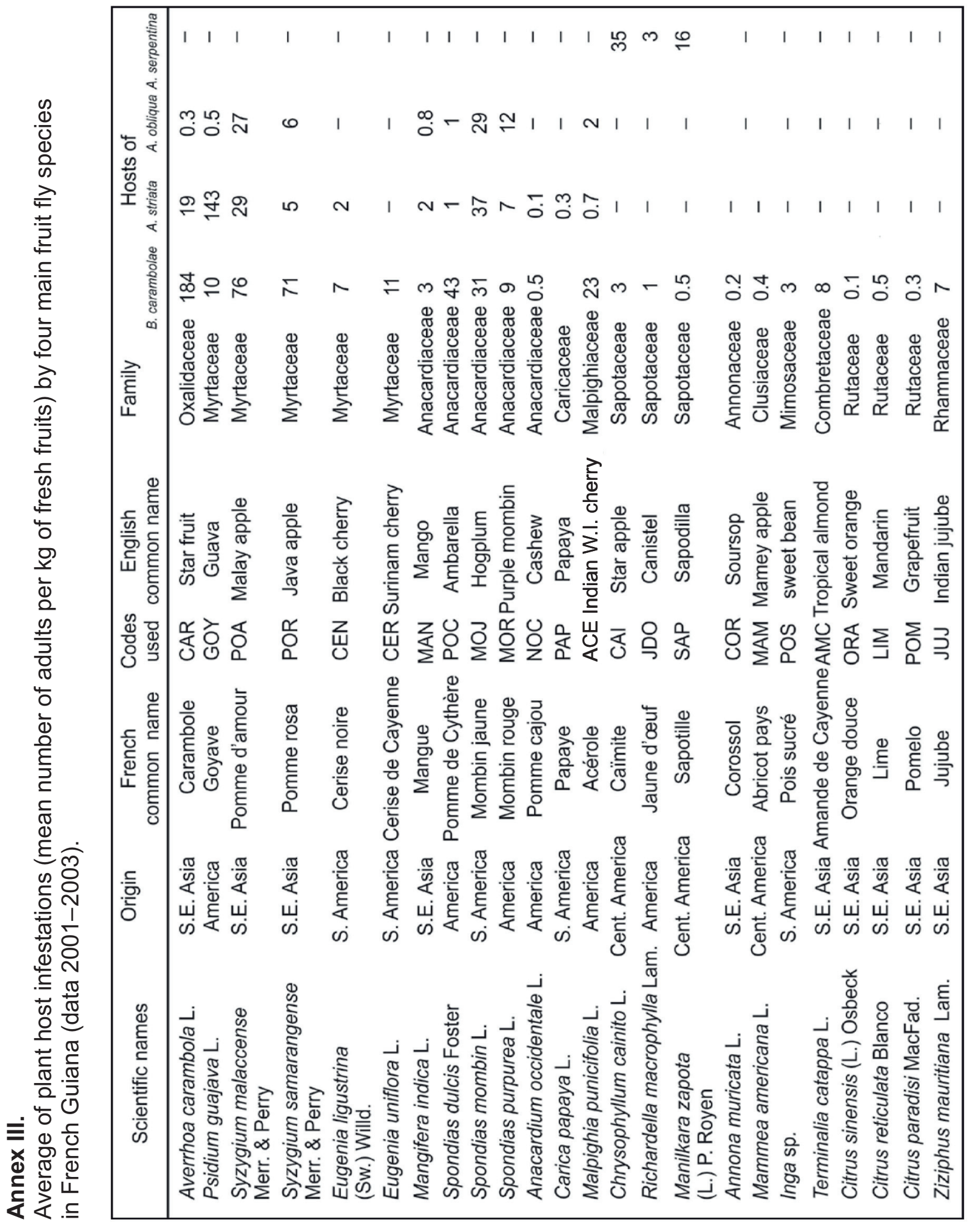



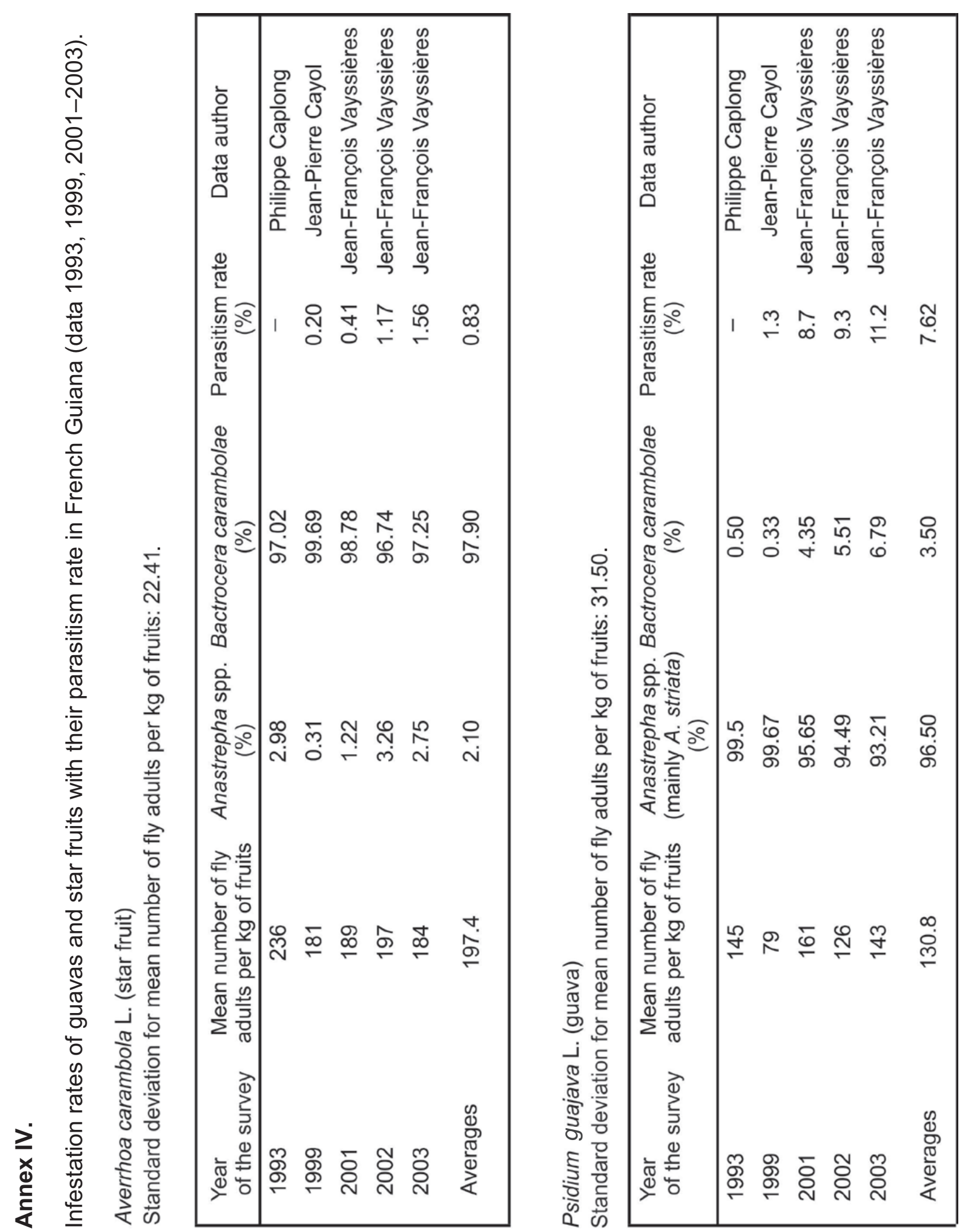


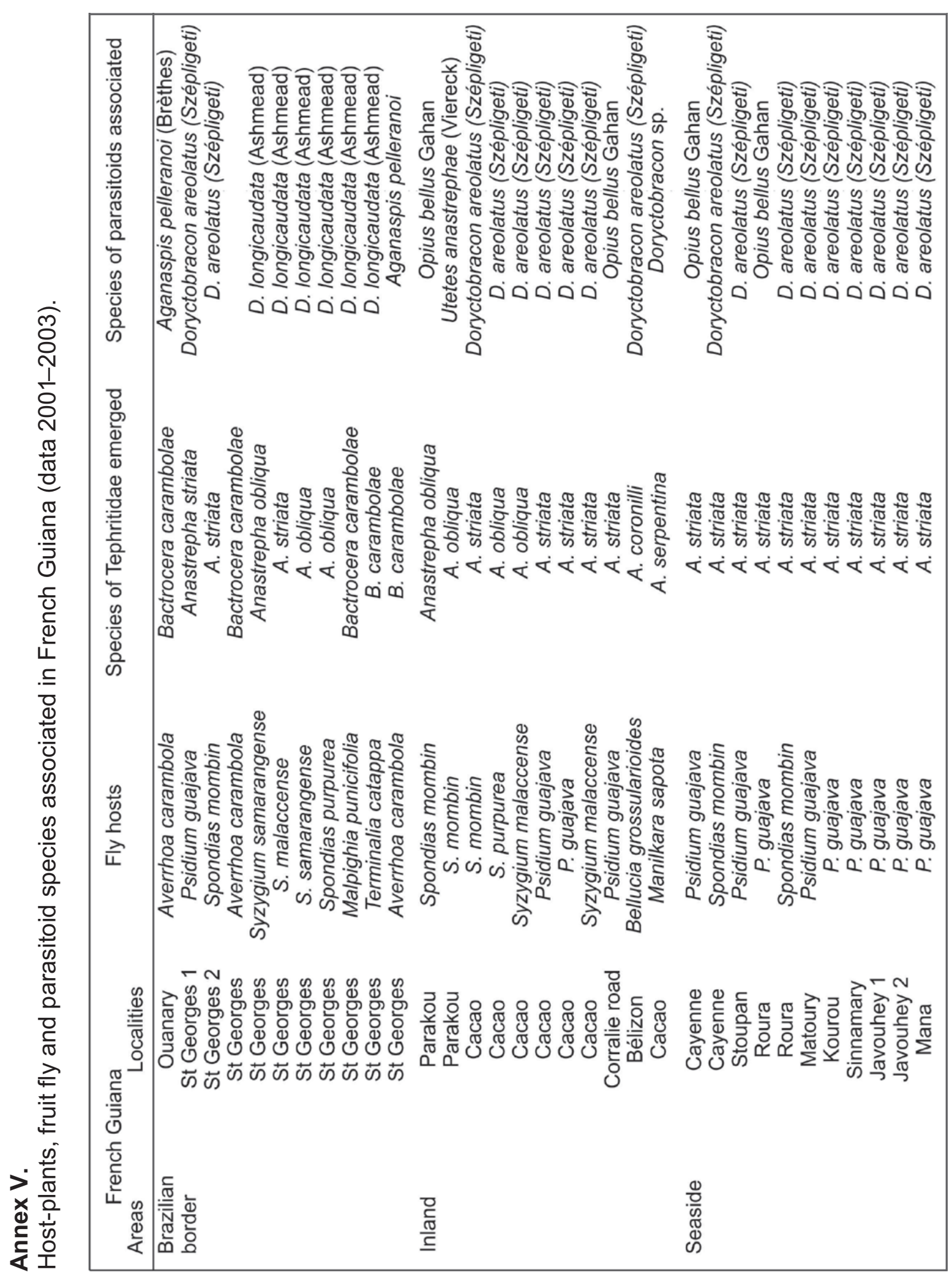

